\title{
Elemental signatures of Pomacentrus coelestis otoliths at multiple spatial scales on the Great Barrier Reef, Australia
}

\author{
Heather M. Patterson ${ }^{1,3, *}$, Michael J. Kingsford ${ }^{1}$, Malcolm T. McCulloch ${ }^{2}$ \\ ${ }^{1}$ School of Marine Biology and Aquaculture, James Cook University, Townsville, Queensland 4811, Australia \\ ${ }^{2}$ Research School of Earth Sciences, Australian National University, Canberra, ACT 0200, Australia \\ ${ }^{3}$ Present address: Department of Zoology, University of Melbourne, Victoria 3010, Australia
}

\begin{abstract}
Elemental signatures in both the natal and post-settlement regions of otoliths from newly settled Pomacentrus coelestis were measured from multiple sites, reefs, years and reef clusters at different latitudes on the Great Barrier Reef, Australia. Significant differences in latitude and year were found for $\mathrm{Sr} / \mathrm{Ca}$ and $\mathrm{Ba} / \mathrm{Ca}$ in the post-settlement portion of the otoliths, and discriminant function analyses identified clear separations in otolith signatures from different reef clusters and years. The spatial and annual variation found in the post-settlement signatures was similar to that determined for the brooding damselfish Acanthochromis polyacanthus, and suggests that these 2 species record environmental variation in a similar manner. This similarity also extended to reefs, although some reefs showed persistent trends for individual elemental ratios. However, the natal portion of the otoliths proved less useful in discriminating groups, and appeared to be decoupled from the postsettlement portion of the otoliths. Such a decoupling could be the result of differences in the food source during the natal period, protein content of the 2 otolith portions which could potentially influence affinity for trace elements, or ontogenetic changes in the depositional process itself. Our findings indicate that robust elemental signatures are likely to be found among clusters of reefs rather than individual reefs, which has important ramifications for future studies attempting to discriminate reef fish populations.
\end{abstract}

KEY WORDS: Reef fish · Otolith chemistry $\cdot$ Inductively coupled plasma - mass spectrometry $\cdot$ Great Barrier Reef · Spatial scale

\section{INTRODUCTION}

The prevailing paradigm in marine ecological theory has long been that marine populations are open systems, with local production of larvae decoupled from local recruitment dynamics (Thorson 1950). This view stems from the fact that most marine organisms have a pelagic larval stage as part of their early life history, thus creating the potential for widespread dispersal and the formation of a larval pool from multiple source areas (Roughgarden et al. 1988, Caley et al. 1996). This theory has been supported in the past by several lines of evidence including genetic studies that have found populations to be panmictic over large spatial scales (e.g. Shulman \& Bermingham 1995), and the idea that marine larvae are essentially passive particles that are subject to advection from their source area (Williams et al. 1984). In addition, the very existence of a dispersive stage in the life history of marine organisms has been cited as evidence that dispersal conveys selective advantages (see Strathmann et al. 2002 for a review).

The theory of open populations in marine systems has recently been questioned, and evidence that once supported this theory is being reinterpreted using new technology (Jones et al. 1999, Swearer et al. 1999). For example, although genetic evidence has indicated panmixia on evolutionary time scales, little direct evidence exists supporting open populations over ecolog- 
ical time scales (Thorrold et al. 2002). Recent genetic studies using advanced techniques and more sensitive markers have shown that differences in gene frequencies do exist, even between geographically close populations (10s to $100 \mathrm{~s}$ of $\mathrm{km}$; Barber et al. 2000, Taylor \& Hellberg 2003). In addition, it is known that little gene flow (i.e. $<1 \%$ exchange; Kimura \& Maruyama 1971) between otherwise distinct populations can homogenize allele frequencies, and thus genetic studies may underestimate the degree of population structure that exists. Recent studies have also demonstrated that marine larvae are not the passive particles they have historically been portrayed to be, but instead possess a suite of sensory abilities that may aid in navigation (Kingsford et al. 2002) and can be very competent swimmers (Leis \& Carson-Ewart 1997, Stobutzki \& Bellwood 1997, Fisher et al. 2000), capable of influencing their trajectories and using oceanographic features to their advantage (Sponaugle et al. 2002). Alternative interpretations of evidence commonly cited as support for the open population model include the idea that dispersive abilities could minimize predation, break parasite cycles, and increase access to rich food sources (Swearer et al. 2002).

Several recent studies have indicated that selfrecruitment may be more pervasive for reef fish than was previously recognized. Jones et al. (1999) chemically tagged the eggs of a common damselfish Pomacentrus amboinensis around Lizard Island (LI) in the Great Barrier Reef (GBR) with tetracycline. They then collected potential settlers in light traps and examined the otoliths to determine how many marked fish were returning to LI. They estimated that 15 to $60 \%$ of the $P$. amboinensis around LI could be self-recruiting. Similar self-recruitment estimates were calculated by Swearer et al. (1999), who used natural otolith signatures from coastal and open ocean areas to examine the source of recruits of Thalassoma bifasciatum to St. Croix (U.S. Virgin Islands). In addition, a study using Eulerian and Lagrangian flow models coupled with realistic current speeds and linear mortality estimates demonstrated that reef fish populations in Barbados were likely to be sustained by larvae originating from Barbados, rather than the closest neighbouring reefs, $>100 \mathrm{~km}$ away (Cowen et al. 2000).

We examined otolith chemistry as a means of estimating self-recruitment levels in the neon damselfish Pomacentrus coelestis to several reefs in both the northern and southern GBR. Such estimates of selfrecruitment have implications for the future management of the GBR, including the identification of stocks and the implementation of Marine Protected Areas (MPAs). We accomplished this by comparing the elemental signatures from both the natal and postsettlement area of the $P$. coelestis otoliths. In addition, we compared the elemental signatures of $P$. coelestis with signatures established for the non-dispersing damselfish Acanthochromis polyacanthus collected at multiple spatial scales (10s of m to 1000s of kms; H. M. Patterson \& M. J. Kingsford unpubl.). This provided a means of not only ground-truthing the $P$. coelestis signatures, but also provided (as far as we are aware) the only direct otolith chemistry classification using 2 different species.

\section{MATERIALS AND METHODS}

Fish collections. Pomacentrus coelestis (12.4 to $26.8 \mathrm{~mm} \mathrm{SL}$; mean $\pm \mathrm{SE}=16.2 \pm 0.2 \mathrm{~mm}$ ) were collected from reef clusters in both the northern GBR around Lizard Island ( $\mathrm{LI}_{;} 14^{\circ} 40^{\prime} \mathrm{S}, 145^{\circ} 28^{\prime} \mathrm{E}$ ) and in the southern GBR around One Tree Island (OTI; $\left.23^{\circ} 30^{\prime} \mathrm{S}, 152^{\circ} 06^{\prime} \mathrm{E}\right)$ For brevity, this spatial scale is hereafter referred to as 'latitude'. In the northern GBR the 4 reefs sampled were Lizard, Northern Direction, MacGillivray, and Eyrie, while in the southern GBR the 4 reefs comprised One Tree, Heron, Sykes and Lamont (Fig. 1). Collections were made in austral summer 2002 in the northern GBR and austral summer 2001 and 2002 in the southern GBR. Five fish were collected from 4 sites within each reef. In some cases, site varied among collections, depending on our ability to return to the same site and fish availability at each site.

Otolith preparation and analysis. The sagittae were dissected using an acid-washed glass probe and plastic forceps and adhering tissue was removed. Otoliths were then triple-rinsed in Milli-Q water, dried in a Class-100 laminar flow hood, and stored in clean microcentrifuge tubes. Otoliths were then embedded in Epofix resin (Struers) and sectioned to a thickness of approximately $2 \mathrm{~mm}$ using a Buehler Isomet low-speed diamond saw to remove excess resin. Blocks were first rough-polished using grit size 800 sandpaper on a motorized grinding wheel, and then fine-polished using a combination of the grinding wheel and $3 \mu \mathrm{m}$ lapping film to remove scratches from the surface of the otolith. The blocks were polished down to the core on both sides of the otolith until the core region and outer rings of the otoliths were both clearly visible. To reduce overall equilibration time associated with changing samples in the LA-ICP-MS (laser ablation inductively coupled plasma - mass spectrometer) sample chamber, 10 otoliths were affixed to each slide. The upper surface of the otoliths was kept free of any crystal bond that could block the laser.

The LA-ICP-MS used was a Resonetics LPX120i ArF excimer laser system $(\lambda=193 \mathrm{~nm})$ coupled with a $7500 \mathrm{~s}$ Series Agilent ICP-MS (for a more extensive description of the system see Eggins et al. 1998 and Sinclair et 


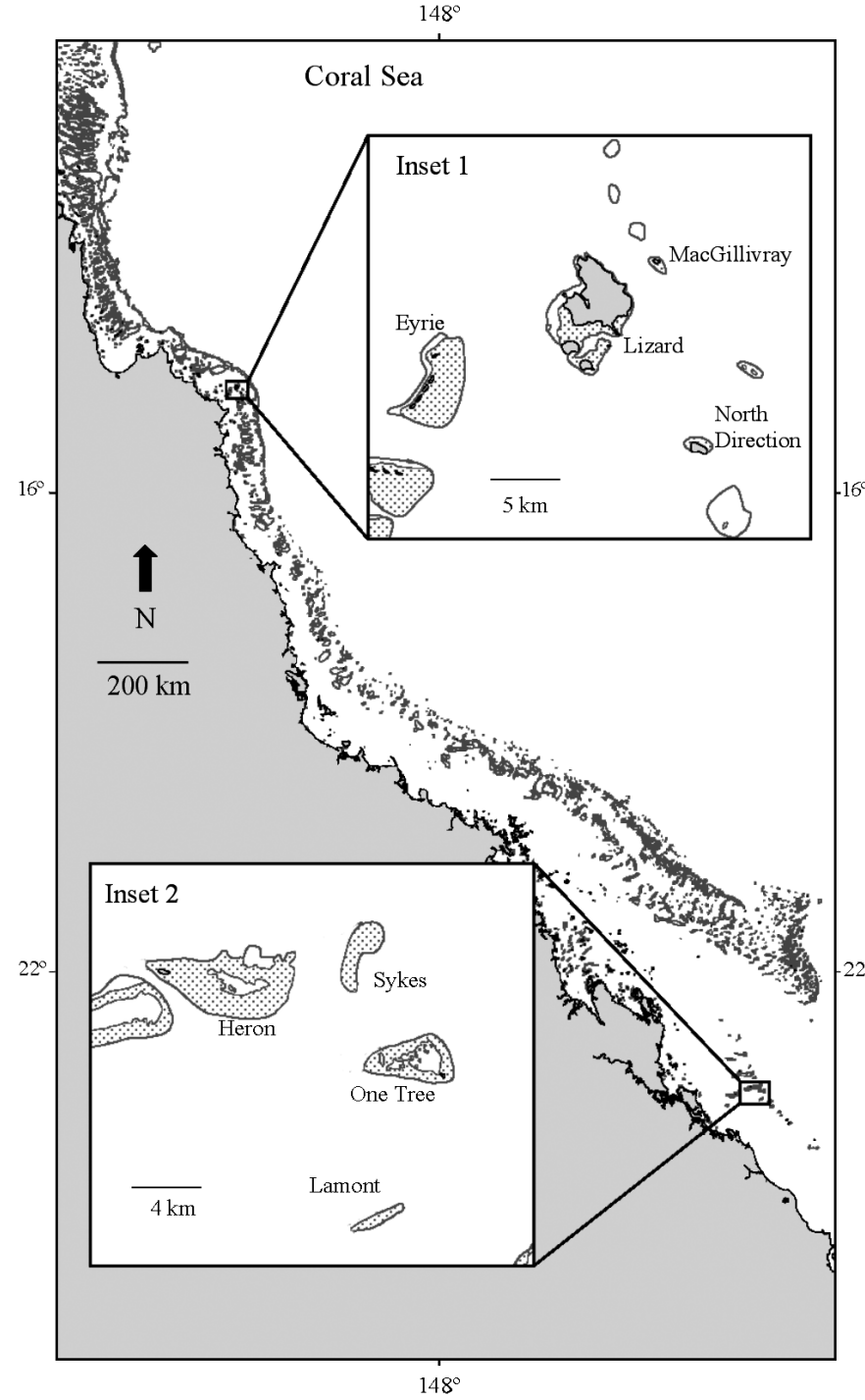

Fig. 1. Northeastern coast of Australia and the Great Barrier Reef. Insets 1 and 2 show northern and southern reefs used in this study, respectively. Data courtesy of the Great Barrier Reef Marine Park Authority

al. 1998). The calibration of the ICP-MS was achieved using the certified reference material NIST 612 (National Institute of Standards and Technology; Gaithersburg, MD, USA). Relative standard deviation (RSD) values for the standard were $<5 \%$. Each otolith was pre-ablated to remove surface contamination using a mask in the shape of a square slit $\sim 530 \times$ $530 \mu \mathrm{m}$. The pre-ablation procedure consisted of 10 individual laser pulses at $100 \mathrm{MJ}$ energy, with each pulse estimated to remove $0.1 \mu \mathrm{m}$ otolith pulse $^{-1}$ (Eggins et al. 1998). The mask was then changed to a rectangular slit $5 \mu \mathrm{m}$ wide perpendicular to the growth axis and $50 \mu \mathrm{m}$ long parallel to the growth axis, creating a crater $\sim 4 \mu \mathrm{m}$ deep. The laser was then pulsed at $10 \mathrm{~Hz}$ using $100 \mathrm{MJ}$ energy across the surface of the otolith, passing across the core. The laser moved across the otolith at a speed of $6.13 \mu \mathrm{m} \mathrm{s}^{-1}$, allowing 7.4 data points to be collected per mask footprint (crater $=5 \times 50$ $\times 4 \mu \mathrm{m}$ ). Background levels and standards (NIST 612) were collected before and after each series, with each series comprising a maximum of 5 otoliths.

Otoliths were analysed for ${ }^{26} \mathrm{Mg},{ }^{43} \mathrm{Ca},{ }^{55} \mathrm{Mn},{ }^{88} \mathrm{Sr}$, and ${ }^{138} \mathrm{Ba}$, as a preliminary analysis of 3 otoliths identified these elements as detectable in sufficient quantities above background levels. Calcium was used as an internal standard. Limits of detection (LOD) $(3 \sigma$ in ppm) were calculated as: ${ }^{26} \mathrm{Mg} 1.47,{ }^{43} \mathrm{Ca} 0.11,{ }^{55} \mathrm{Mn}$ $0.11,{ }^{88} \mathrm{Sr} 0.027,{ }^{138} \mathrm{Ba} 0.014$. All elemental data were expressed as molar ratios to Ca. An Excel macro was used to reprocess elemental data and backgroundsubtracted measured elemental values. A linear interpolation between the NIST 612 measurements taken before and after the samples was used to correct for any instrument drift.

Image analysis. After the otoliths had been sampled with the LA-ICP-MS, the increments were counted and measured using an image-analysis system. A previous study confirmed that Pomacentrus coelestis deposit increments on a daily basis (Flood 2000). A drop of immersion oil was placed on each otolith to enhance its readability and an image of each otolith was captured and saved at a magnification of $400 \times$ using a Leica DC300 digital video camera. Using the software package Leica IM50, the increments on the non-sulcal, or ventrolateral side of each otolith were measured; the sulcus of the otolith was not used for any analyses, as the increments in the sulcus were compressed and often difficult to discern and measure. Laser footprints, and the corresponding daily increments, were also assigned a code based on the life history stage to which they were linked. The first 4 footprints from the dorsolateral margin of the core towards the ventrolateral margin of the otolith, which corresponded to the core and the first 1 to 2 daily rings, were designated the 'natal region', while the 5th footprint through to the settlement mark were designated the 'pre-settlement region'. All footprints after the settlement mark were designated the 'post-settlement region'. The settlement mark was established based on a sharp decline in increment width (Wilson \& McCormick 1999). The footprints bordering a different life history region of the otolith were not used for any analyses. For this study, only data from the natal and post-settlement regions were used.

Statistical analysis. A fully nested ANOVA with the random factors of latitude, reefs within latitude, and sites within reefs within latitude was used to determine spatial scales of variation in otolith chemistry. Data were tested for homogeneity of variances using Cochran's $C$-test, and in all cases were found to be 
homogenous. Fish from the northern and southern GBR collected in 2002 were used for this analysis. Variance components were also determined for this design to assess which factors contributed the most variation.

A 4-factor partially hierarchical ANOVA with the factors year, reef, year-reef interaction, and site nested within the interaction was used to determine the annual and spatial variation of Pomacentrus coelestis elemental signatures from the southern GBR in 2001 and 2002. Due to logistical constraints, it was not possible to examine annual variation in signatures in the northern GBR for this species. Both signatures from the natal region and post-settlement region of the otoliths were used in the ANOVAs described above. Natal and post-settlement data could not be analysed in the same analysis as they were obtained from the same fish (i.e. were not independent). Variance components were not calculated for this analysis as the design would need to be partitioned into separate years before variance components could be logically calculated (Underwood \& Petraitis 1993).

To reduce the possibility of high $\mathrm{Sr} / \mathrm{Ca}$ values skewing the multivariate results, all elemental data were $\ln (x+1)$ transformed prior to multivariate analysis. Multivariate analysis consisted of discriminant function analyses (DFA) and jackknife cross-validation to assess how accurately fish could be assigned to a factor (e.g. latitude, year, reef) using otolith chemistry. A quadratic DFA was used because a Box's $M$-test had determined that variance-covariance matrices were unequal. $\mathrm{Mg}$ values in the analyses of Acanthochromis polyacanthus were regarded as unreliable (H. M. Patterson \& M. J. Kingsford unpubl. data), and therefore $\mathrm{Mg}$ was removed from further analyses to allow for comparisons of the signatures of Pomacentrus coelestis with those of A. polyacanthus. We also used A. polyacanthus as the training data set and $P$. coelestis as the test data set to determine how accurately elemental signatures for one species could classify another species. These comparisons were done for latitude and year only, as it was not possible to consistently and accurately classify otoliths to individual reefs. Although LA-ICP-MS and solutionbased ICP-MS are known to have different sensitivities, we assumed standardizing elemental data to $\mathrm{Ca}$ and using $\ln (x+1)$ transformations would eliminate any absolute differences between the data from these 2
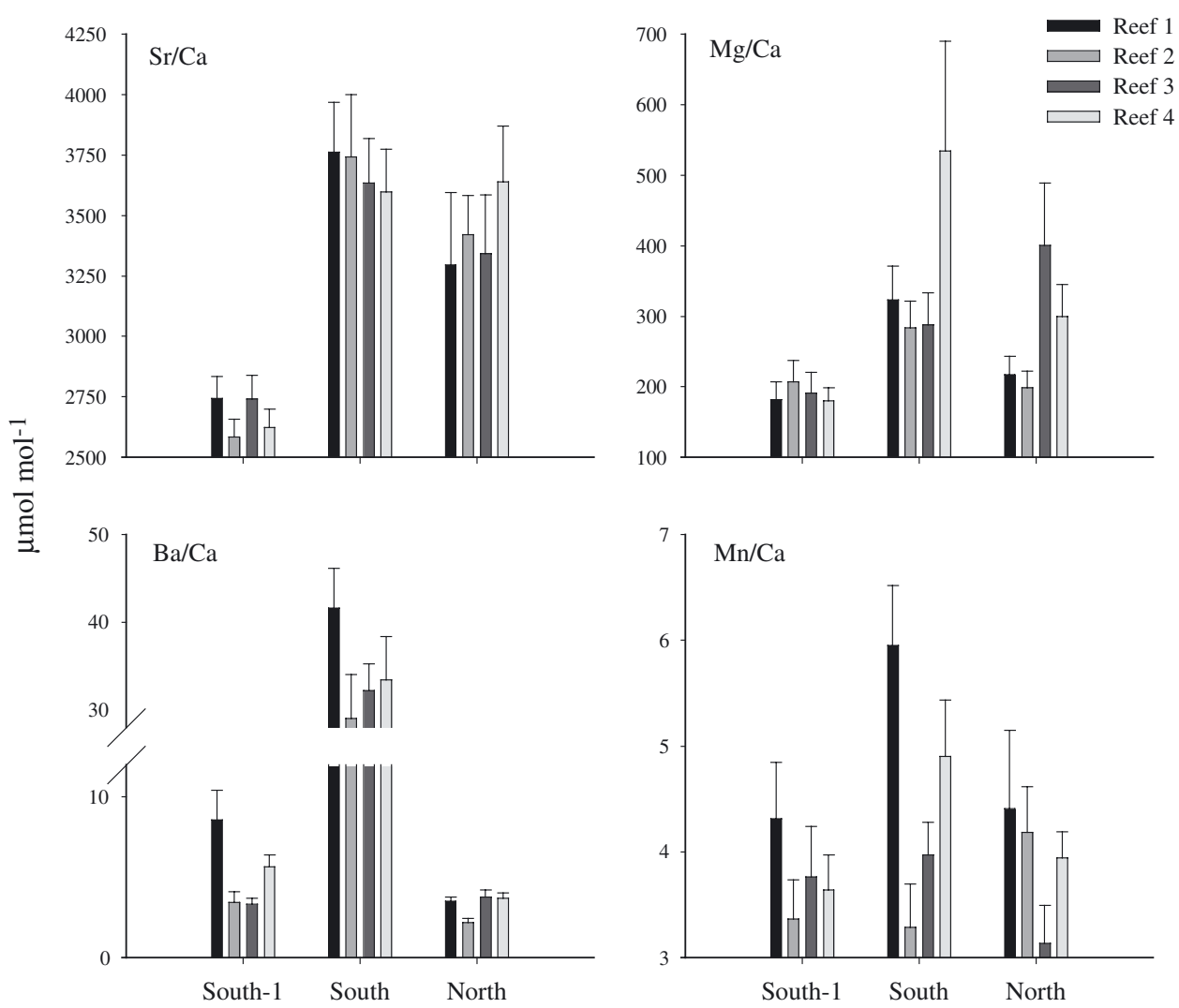

Fig. 2. Pomacentrus coelestis. Elemental concentrations $(+\mathrm{SE})$ in post-settlement portion of otoliths ( $\mathrm{n}=20$ per reef) from the southern GBR in 2001 (South-1), and 2002 (South) and the northern GBR in 2002. Reefs (1 to 4) in the southern GBR for both years were Heron, Lamont, One Tree, and Sykes. Reefs (1 to 4) in the northern GBR were Eyrie, Lizard, MacGillivray and North Direction 
Table 1. Pomacentrus coelestis. ANOVA results for fish $(\mathrm{n}=5)$ from the northern and southern Great Barrier Reef in 2002 using post-settlement and natal signatures. ns: not significant, ${ }^{*} \mathrm{p}<0.05,{ }^{* *} \mathrm{p}<0.01,{ }^{* * *} \mathrm{p}<0.001$

\begin{tabular}{|c|c|c|c|c|c|c|c|c|c|}
\hline \multirow[t]{2}{*}{ Source } & \multirow[t]{2}{*}{ df } & \multicolumn{2}{|c|}{$\mathrm{Mg} / \mathrm{Ca}$} & \multicolumn{2}{|c|}{$\mathrm{Mn} / \mathrm{Ca}$} & \multicolumn{2}{|c|}{$\mathrm{Sr} / \mathrm{Ca}$} & \multicolumn{2}{|c|}{$\mathrm{Ba} / \mathrm{Ca}$} \\
\hline & & MS & $F$ & MS & $F$ & MS & $F$ & MS & $F$ \\
\hline \multicolumn{10}{|c|}{ Post-settlement signature } \\
\hline Latitude & 1 & $2.5 \times 10^{5}$ & $1.08^{\mathrm{ns}}$ & 14.9 & $0.91^{\mathrm{ns}}$ & $1.2 \times 10^{6}$ & $4.57^{\mathrm{ns}}$ & 37884.5 & $129.43^{* *}$ \\
\hline Reef(Latitude) & 6 & $2.3 \times 10^{5}$ & $0.83^{\mathrm{ns}}$ & 16.5 & $2.62^{* *}$ & $2.7 \times 10^{5}$ & $0.20^{\mathrm{ns}}$ & 292.7 & $1.76^{\mathrm{ns}}$ \\
\hline Site(Reef(Latitude)) & 24 & $2.7 \times 10^{5}$ & $1.87^{\mathrm{ns}}$ & 6.3 & $1.53^{\mathrm{ns}}$ & $1.4 \times 10^{6}$ & $2.15^{* *}$ & 248.9 & $1.32^{\mathrm{ns}}$ \\
\hline Error & 128 & $2.3 \times 10^{5}$ & & 4.1 & & $6.4 \times 10^{5}$ & & 188.2 & \\
\hline \multicolumn{10}{|l|}{ Natal signature } \\
\hline Latitude & 1 & $4.3 \times 10^{4}$ & $1.22^{\mathrm{ns}}$ & 27.9 & $19.56^{* *}$ & $4.7 \times 10^{4}$ & $0.56^{\mathrm{ns}}$ & 6.8 & $5.97^{*}$ \\
\hline Reef(Latitude) & 6 & $3.5 \times 10^{4}$ & $1.03^{\mathrm{ns}}$ & 1.4 & $0.67^{\mathrm{ns}}$ & $8.4 \times 10^{4}$ & $0.88^{\mathrm{ns}}$ & 1.2 & $0.34^{\mathrm{ns}}$ \\
\hline Site(Reef(Latitude)) & 24 & $3.4 \times 10^{4}$ & $0.99^{\mathrm{ns}}$ & 2.1 & $0.87^{\mathrm{ns}}$ & $9.5 \times 10^{4}$ & $1.46^{\mathrm{ns}}$ & 1.0 & $0.99^{\mathrm{ns}}$ \\
\hline Error & 128 & $3.4 \times 10^{4}$ & & 2.5 & & $6.5 \times 10^{4}$ & & 1.0 & \\
\hline
\end{tabular}

instruments, thus making them directly comparable. In addition, while elemental fractionation is a possibility, it was probably negligible in this case due to the elements examined and their behaviour during ablation and in the plasma torch. We used jittered dot density plots of derived canonical variates to illustrate separation between groups in multivariate space.

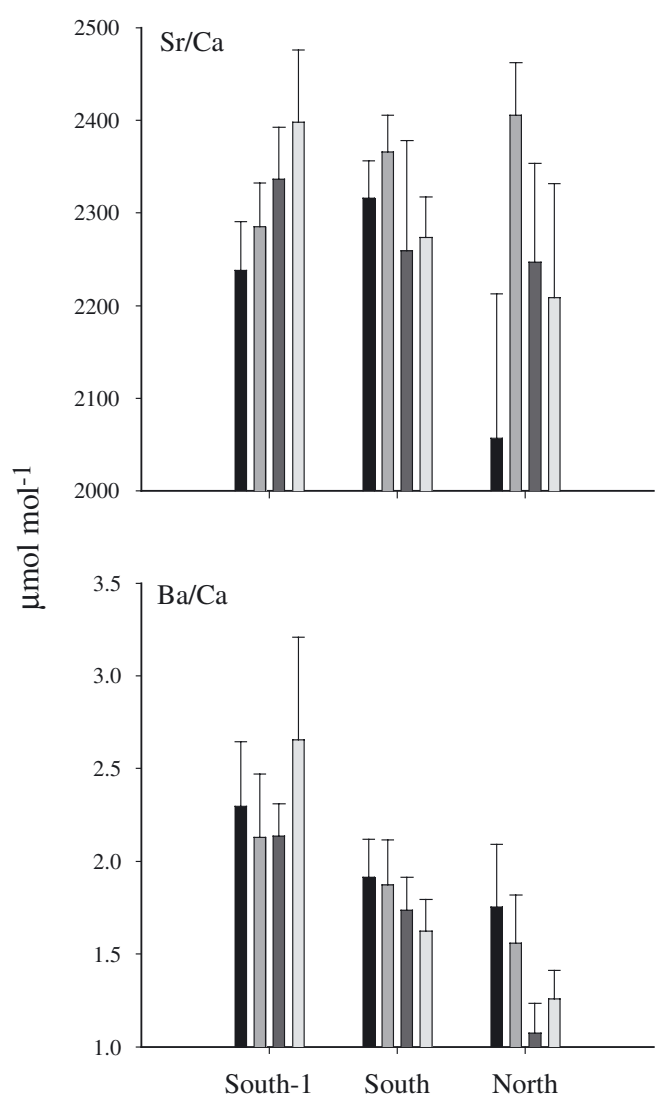

\section{RESULTS}

$\mathrm{Ba} / \mathrm{Ca}$ varied strongly between latitudes for both the natal and post-settlement regions of the otoliths in 2002 (Table 1, Figs. 2 \& 3). Mn/Ca also differed at the level of reefs within latitudes for the postsettlement signatures and latitude for the natal signa-
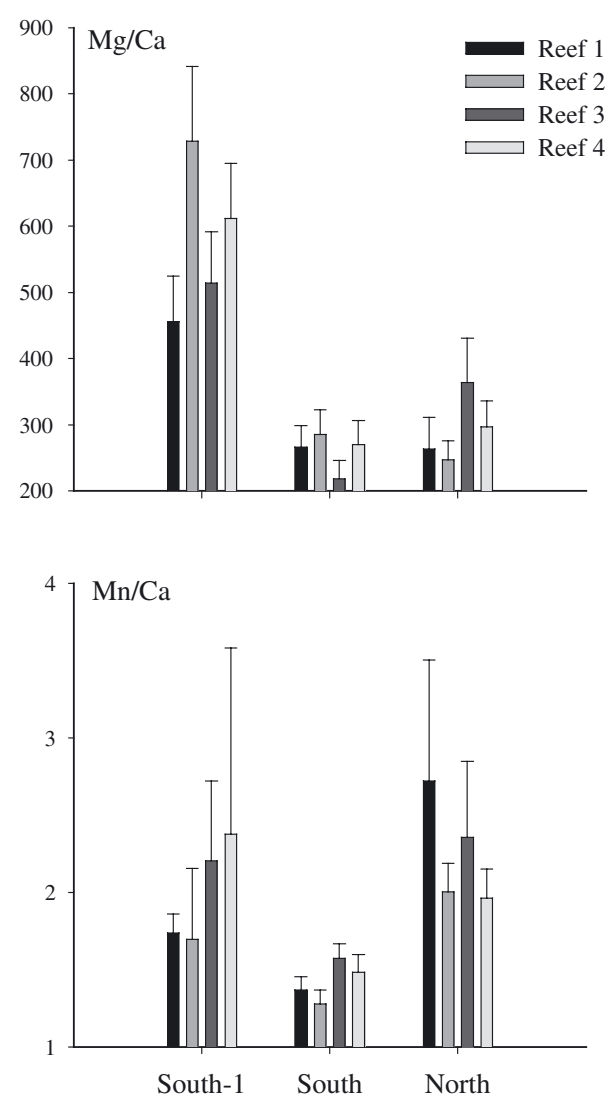

Fig. 3. Pomacentrus coelestis. Elemental concentrations (+SE) in natal portion of otoliths (n = 20 per reef) from the southern GBR in 2001 (South-1), and 2002 (South) and the northern GBR in 2002. Reef numbers as in Fig. 2 
Table 2. Pomacentrus coelestis. Variance components for each factor in ANOVA design in Table 1 expressed as percentage of total variation for post-settlement and natal signatures

\begin{tabular}{|lcccc|}
\hline Source & $\mathrm{Mg} / \mathrm{Ca}$ & $\mathrm{Mn} / \mathrm{Ca}$ & $\mathrm{Sr} / \mathrm{Ca}$ & $\mathrm{Ba} / \mathrm{Ca}$ \\
\hline Post-settlement signature & & & & \\
Latitude & 0.1 & 0 & 1.2 & 69.9 \\
Reef(Latitude) & 0 & 10.0 & 0 & 0.3 \\
Site(Reef(Latitude)) & 3.6 & 8.6 & 14.1 & 1.8 \\
Error & 96.3 & 81.4 & 84.7 & 28.0 \\
Natal signature & & & & \\
Latitude & 0.3 & 11.9 & 0 & 6.8 \\
Reef(Latitude) & 0.2 & 0 & 0 & 0.9 \\
Site(Reef(Latitude)) & 0 & 0 & 3.5 & 0 \\
Error & 99.5 & 88.1 & 96.5 & 92.3 \\
\hline
\end{tabular}

lai's Trace, $F_{3,156}=15.50, \mathrm{p}<0.0001$ ) for the natal and post-settlement regions, respectively. Despite trends for individual elements to be persistently higher at some reefs (e.g. Ba/Ca at Heron Island), and high classification accuracies for some reefs (i.e. $70 \%$ for Lizard Island), it was difficult to accurately classify otoliths to reef within a latitude (Table 4). A DFA by year for the 2 collections in the southern GBR indicated classification accuracies of $35 \%$ and $78 \%$ (Pillai's Trace, $F_{3,156}=$ $2.43, \mathrm{p}>0.05$ ), and 89 and $89 \%$ (Pillai's Trace, $F_{3,156}=$ $91.67, \mathrm{p}<0.0001)$ for the natal and post-settlement signatures, respectively. Again, reefs within these years could not be readily distinguished based on otolith chemistry (Table 5). tures. In contrast, Sr/Ca varied only for sites in the post-settlement region and $\mathrm{Mg} / \mathrm{Ca}$ did not vary at any level for either region of the otolith. Variance components for the post-settlement portion of the otoliths indicated that latitude accounted for $70 \%$ of the variation in $\mathrm{Ba} / \mathrm{Ca}$; factors other than the residual did not account for more than $14 \%$ of the variation for the other elemental ratios (Table 2). In the natal region of the otoliths, variance components indicated that most of the variance for all elemental ratios was at the residual level (Table 2), although latitude accounted for 7 and $11 \%$ of the variation in $\mathrm{Ba} / \mathrm{Ca}$ and $\mathrm{Mn} / \mathrm{Ca}$ ratios, respectively.

Significant differences between years (2001 and 2002) in $\mathrm{Ba} / \mathrm{Ca}$ and $\mathrm{Sr} / \mathrm{Ca}$ ratios were found in the southern GBR for the post-settlement signatures (Table 3). In contrast, natal $\mathrm{Ba} / \mathrm{Ca}$ and Sr/Ca ratios were not significant for any factor. However, significant yearly differences were detected for $\mathrm{Mn} / \mathrm{Ca}$ and $\mathrm{Mg} / \mathrm{Ca}$, and $\mathrm{Mg} / \mathrm{Ca}$ also differed among sites within reefs. Differences among sites obscured differences among reefs within latitudes.

Discriminant function analyses of multielement signatures distinguished differences between latitudes and year. Jittered dot density plots illustrated these separations (Figs. 4 \& 5). A DFA by latitude including otoliths from the northern GBR and both years (2001 and 2002) from the southern GBR had classification accuracies of 68 and $76 \%$ (Pillai's Trace, $F_{3,236}=19.54, \mathrm{p}<0.0001$ ), and 93 and $86 \%$ (Pillai's Trace, $F_{3,236}=84.31, \mathrm{p}<$ 0.0001 ) for the natal and post-settlement regions, respectively. When the 2001 otoliths from the southern GBR were removed from the analysis, the classification accuracies showed little improvement with 56 and $84 \%$ (Pillai's Trace, $F_{3,156}=15.50, \mathrm{p}<0.0001$ ), and 96 and $94 \%$ (Pil-

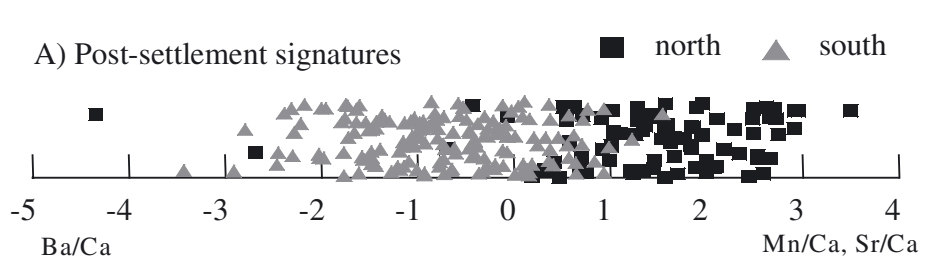

B) Natal signatures

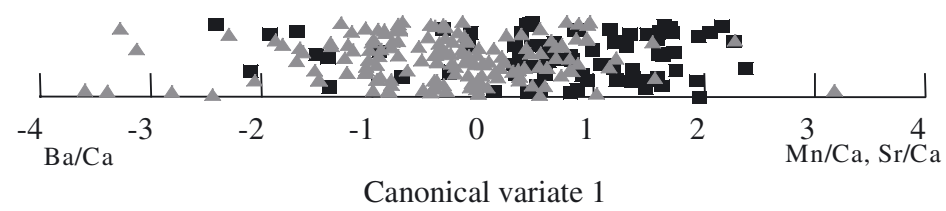

Fig. 4. Pomacentrus coelestis. Jittered dot density plots of canonical variate 1 from (A) post-settlement and (B) natal regions of otoliths from reefs in the northern and southern GBR (north, $\mathrm{n}=80$; south, $\mathrm{n}=160$ ). Elemental ratios on abscissas indicate which ratios contributed to positive and negative distribution of canonical variates

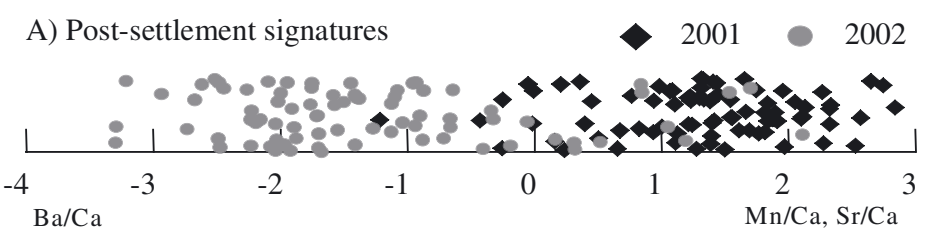

B) Natal signatures

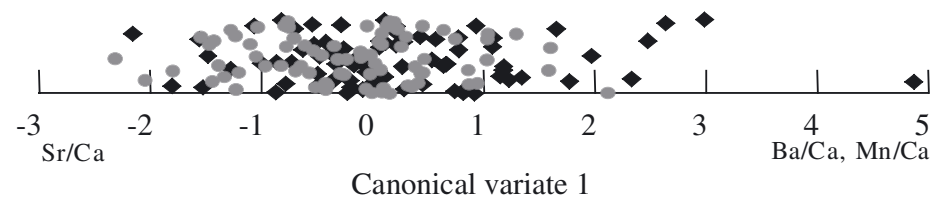

Fig. 5. Pomacentrus coelestis. Jittered dot density plots of canonical variate 1 for (A) post-settlement and (B) natal signatures of otoliths from the Capricorn-Bunker group in 2 years $(\mathrm{n}=80$ per year). Elemental ratios on abscissas indicate which ratios contributed to positive and negative distribution of canonical variates 
Table 3. Pomacentrus coelestis. ANOVA results for fish from the southern GBR in 2001 and $2002(\mathrm{n}=5)$ using post-settlement and natal signatures. ns: not significant, ${ }^{*} \mathrm{p}<0.05,{ }^{* *} \mathrm{p}<0.01,{ }^{* * *} \mathrm{p}<0.001$

\begin{tabular}{|c|c|c|c|c|c|c|c|c|c|}
\hline \multirow[t]{2}{*}{ Source } & \multirow[t]{2}{*}{$\mathrm{df}$} & \multicolumn{2}{|c|}{$\mathrm{Mg} / \mathrm{Ca}$} & \multicolumn{2}{|c|}{$\mathrm{Mn} / \mathrm{Ca}$} & \multicolumn{2}{|c|}{$\mathrm{Sr} / \mathrm{Ca}$} & \multicolumn{2}{|c|}{$\mathrm{Ba} / \mathrm{Ca}$} \\
\hline & & MS & $F$ & MS & $F$ & MS & $F$ & MS & $F$ \\
\hline \multicolumn{10}{|c|}{ Post-settlement signature } \\
\hline Year & 1 & $1.1 \times 10^{6}$ & $6.85^{\mathrm{ns}}$ & 23.0 & $3.37^{\mathrm{ns}}$ & $4.3 \times 10^{7}$ & $607.33^{* * *}$ & 33221.2 & $340.66^{* * *}$ \\
\hline Reef & 3 & $1.2 \times 10^{5}$ & $0.77^{\mathrm{ns}}$ & 23.2 & $3.40^{\text {ns }}$ & $1.5 \times 10^{5}$ & $2.50^{\mathrm{ns}}$ & 598.6 & $6.14^{\mathrm{ns}}$ \\
\hline $\mathrm{Y} \times \mathrm{R}$ & 3 & $1.6 \times 10^{5}$ & $0.68^{\text {ns }}$ & 6.8 & $1.67^{\mathrm{ns}}$ & $7.1 \times 10^{4}$ & $0.10^{\text {ns }}$ & 97.5 & $0.36^{\text {ns }}$ \\
\hline $\operatorname{Site}(Y \times R)$ & 24 & $2.4 \times 10^{6}$ & $1.13^{\text {ns }}$ & 4.1 & $0.99^{\text {ns }}$ & $7.1 \times 10^{5}$ & $1.77^{*}$ & 274.8 & $1.41^{\mathrm{ns}}$ \\
\hline Error & 128 & $2.1 \times 10^{5}$ & & 4.1 & & $4.0 \times 10^{5}$ & & 194.9 & \\
\hline \multicolumn{10}{|c|}{ Natal signature } \\
\hline Year & 1 & $4.0 \times 10^{6}$ & $36.30^{* *}$ & 13.4 & $23.20^{*}$ & $8.4 \times 10^{3}$ & $0.09^{\mathrm{ns}}$ & 9.2 & $7.49^{\text {ns }}$ \\
\hline Reef & 3 & $1.9 \times 10^{5}$ & $1.72^{\mathrm{ns}}$ & 2.1 & $3.57^{\mathrm{ns}}$ & $3.9 \times 10^{4}$ & $0.42^{\text {ns }}$ & 0.4 & $0.34^{\mathrm{ns}}$ \\
\hline $\mathrm{Y} \times \mathrm{R}$ & 3 & $1.1 \times 10^{5}$ & $0.49^{\text {ns }}$ & 0.6 & $0.13^{\text {ns }}$ & $9.3 \times 10^{4}$ & $1.91^{\mathrm{ns}}$ & 1.2 & $0.47^{\text {ns }}$ \\
\hline Site $(Y \times R)$ & 24 & $2.3 \times 10^{5}$ & $3.65^{* * *}$ & 4.5 & $0.88^{\text {ns }}$ & $4.9 \times 10^{4}$ & $0.84^{\mathrm{ns}}$ & 2.6 & $1.58^{\mathrm{ns}}$ \\
\hline Error & 128 & $6.2 \times 10^{4}$ & & 5.1 & & $5.8 \times 10^{4}$ & & 1.7 & \\
\hline
\end{tabular}

Table 4. Results of a jack-knife cross-validation procedure for each reef in the northern (Pillai's Trace, $F_{9,288}=3.15, \mathrm{p}<0.01$ ) and southern (Pillai's Trace, $F_{9,288}=2.24, \mathrm{p}<0.05$ ) latitudes using post-settlement signatures, and in the northern (Pillai's Trace, $F_{9,288}=1.27, \mathrm{p}>0.05$ ) and southern (Pillai's Trace, $F_{9,288}=1.31, \mathrm{p}>0.05$ ) latitudes using natal signatures. EY: Eyrie; LZ: Lizard; MC: MacGillivray; ND: North Direction; HR: Heron; LT: Lamont; OT: One Tree; SY: Sykes. Results are given as a percentage of the total number classified to each reef, with correct percentages in bold ( $\mathrm{n}=20$ per reef)

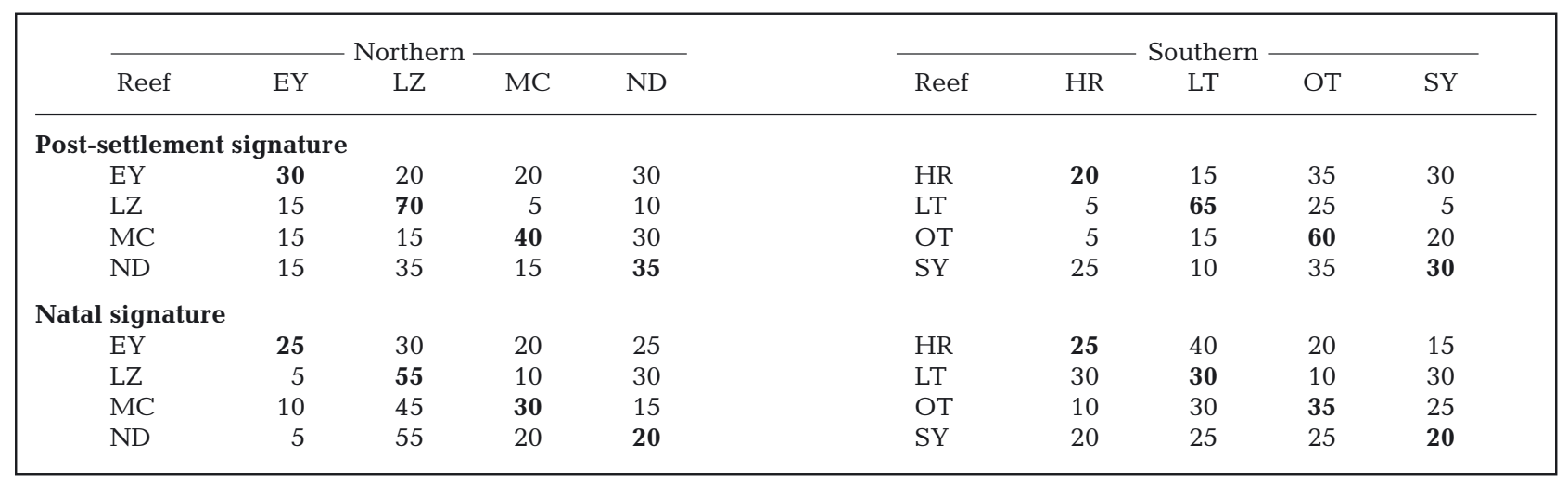

Table 5. Results of a jack-knife cross-validation procedure for each reef in the Capricorn-Bunker group in 2001 (Pillai's Trace, $F_{9,288}=2.24, \mathrm{p}<0.05$ ) and 2002 (Pillai's Trace, $F_{9,288}=3.00, \mathrm{p}<0.01$ ) using post-settlement signatures, and in 2001 (Pillai's Trace, $F_{9,288}=0.94, \mathrm{p}>0.05$ ) and 2002 (Pillai's Trace, $F_{9,288}=1.13, \mathrm{p}>0.05$ ) using natal signatures. HR: Heron; LT: Lamont; OT: One Tree; SY: Sykes. Results are given as a percentage of the total number classified to each reef, with correct percentages in bold $(\mathrm{n}=20$ per reef)

\begin{tabular}{|c|c|c|c|c|c|c|c|c|c|}
\hline \multirow[b]{2}{*}{ Reef } & \multirow[b]{2}{*}{ HR } & \multicolumn{3}{|l|}{2001} & \multirow[b]{2}{*}{ Reef } & \multirow[b]{2}{*}{ HR } & \multirow{2}{*}{$\begin{array}{c}2002 \\
\text { LT }\end{array}$} & \multirow[b]{2}{*}{ OT } & \multirow[b]{2}{*}{ SY } \\
\hline & & LT & OT & SY & & & & & \\
\hline \multicolumn{10}{|c|}{ Post-settlement signature } \\
\hline HR & 35 & 25 & 25 & 15 & HR & 20 & 15 & 35 & 30 \\
\hline LT & 10 & 55 & 30 & 5 & $\mathrm{LT}$ & 5 & 65 & 25 & 5 \\
\hline OT & 5 & 20 & 55 & 20 & OT & 5 & 15 & 60 & 20 \\
\hline SY & 10 & 15 & 5 & 70 & SY & 25 & 10 & 35 & 30 \\
\hline \multicolumn{10}{|c|}{ Natal signature } \\
\hline HR & 55 & 15 & 15 & 15 & HR & 25 & 40 & 20 & 15 \\
\hline LT & 40 & 30 & 25 & 5 & LT & 30 & 30 & 10 & 3 \\
\hline OT & 55 & 10 & 20 & 15 & OT & 10 & 30 & 35 & 25 \\
\hline SY & 35 & 15 & 20 & 30 & SY & 20 & 25 & 35 & 20 \\
\hline
\end{tabular}


Table 6. Pomacentrus coelestis. Summary of discriminant function analyses (DFA) used to classify otoliths. Training column indicates if algorithm was based on Acanthochromis polyacanthus otolith chemistry, or on a portion of the $P$. coelestis otoliths $(\mathrm{NT}=$ natal, $\mathrm{PS}=$ post-settlement); test column indicates the portion of the $P$. coelestis otoliths used as test data set in the classification. The 2 factors used were latitude (columns north and south indicate percentage of otoliths correctly classified to those latitudes), and year (columns 2001 and 2002 indicate percentage of otoliths correctly classified to those years)

\begin{tabular}{|lcrrrr|}
\hline \multirow{2}{*}{ Training } & \multirow{2}{*}{ Test } & \multicolumn{2}{c}{ Latitude } & \multicolumn{2}{c|}{ Year } \\
& & North & South & 2001 & 2002 \\
\hline A. polyacanthus & PS & 98 & 76 & 98 & 80 \\
A. polyacanthus & NT & 99 & 0 & 99 & 0 \\
NT & PS & 85 & 18 & 83 & 6 \\
PS & NT & 98 & 3 & 84 & 8 \\
\hline
\end{tabular}

Algorithms developed using Acanthochromis polyacanthus elemental signatures (H. M. Patterson \& M. J. Kingsford unpubl.) were readily applicable to the post-settlement signatures of Pomacentrus coelestis, although this was not true of the natal signatures (Table 6). A DFA using A. polyacanthus as the training data set correctly classified 98 and $76 \%$ of the postsettlement $P$. coelestis as being from the northern or southern GBR, respectively. Classification accuracies between latitudes using the same training data set and natal signatures as the test data set showed large variation (99 and $0 \%$ ). When the post-settlement portion of the otolith was classified using a DFA of the natal area as the training data set the classification rate was 85 and $18 \%$, while a DFA of the post-settlement signatures as the training data set and the natal signatures as the test data set demonstrated 98 and $3 \%$ classification accuracies, respectively.

This was similar to the pattern seen between 2001 and 2002 in the southern GBR. A DFA derived using Acanthochromis polyacanthus classified $99 \%$ and $0 \%$ of the Pomacentrus coelestis otoliths from 2001 and 2002, respectively, when the natal portion of the otoliths was used as the test data set. Post-settlement signatures, however, could be classified to year with 98 and $80 \%$ accuracy rates, respectively. These classification rates were similar to the rates produced when $P$. coelestis was the training data set. A DFA derived using the natal portion of the otolith and applied to the post-settlement portion produced correct classification rates of 83 and $6 \%$ for 2001 and 2002, respectively. Similarly, the DFA derived using the post-settlement portion of the otolith produced classification accuracies of 84 and $8 \%$, respectively, when applied to the natal portion of the otoliths.

The inconsistency of classification rates for analyses using the natal portion of the Pomacentrus coelestis otoliths appeared to be driven by the inability of the algorithms to adequately distinguish between groups. Thus, a majority of the otoliths were generally lumped into one group, resulting in skewed classification accuracies (e.g. 99 and $0 \%$ for north and south, respectively). However, when the natal portion of the otoliths was not included in the analyses (i.e. post-settlement signatures or Acanthochromis polyacanthus signatures only) the algorithms produced relatively accurate and consistent classification results.

\section{DISCUSSION}

The post-settlement elemental signatures found in Pomacentrus coelestis (this study) were similar to those in the otoliths of Acanthochromis polyacanthus from the same areas (H.M. Patterson \& M.J. Kingsford unpubl.), indicating that these species incorporate elements into their otoliths via similar depositional mechanisms. The large differences observed in $P$. coelestis otoliths between reef clusters and year could potentially be the result of several mechanisms including differences in riverine input, upwelling, and overall differences in water chemistry driven by oceanographic processes. Riverine input was unlikely to be involved in this case, as the reefs examined were well offshore $(>50 \mathrm{~km})$. Upwelling is a more plausible mechanism, particularly in the southern GBR. For example, high Ba/Ca levels from the southern GBR in 2002 were observed in the otoliths, probably reflecting cold-water intrusions indicative of the upwelling known to occur in the southern GBR (Haskew 2002). Similarly, large-scale oceanographic differences between the 2 latitudes examined would influence water chemistry and thus otolith chemistry. Otolith chemistry of fish from the northern GBR was likely influenced by the bifurcation of the Equatorial Current, which is usually located near Lizard Island during the summer months (Burrage et al. 1995). This bifurcation probably delivered water masses to the northern reefs that were quite different in elemental composition to water found in the southern GBR, as the water reaching the southern GBR would have evolved chemically due to mixing processes and inputs encountered as it moved south.

Using post-settlement signatures, it was possible to classify the Pomacentrus coelestis to latitude and year with a high degree of accuracy. In addition, high classification accuracies were observed using discriminant function analyses with Acanthochromis polyacanthus elemental signatures as the training data set. Several studies have examined the otolith chemistry of 2 or more species collected from the same general locations (Edmonds et al. 1995, 1999, Dove et al. 1996, Gillanders \& Kingsford 2003, Swearer et al. 2003) and have 
found interspecific differences in otolith chemistry. However, these studies often collected fish at different times and/or from different sites within location, thus potentially confounding the comparisons. In addition, these studies often used species from different families (but see Gillanders \& Kingsford 2003), probably complicating comparisons by introducing physiological variation (Swearer et al. 2003). To our knowledge, this is the first time a direct classification for 2 species has been done using otolith chemistry, and demonstrates the consistency of the influence of water chemistry, at least on large spatial and temporal scales, even in species with very different early life history strategies.

The consistency of elemental signatures between species was not observed for natal elemental signatures, with poor classification accuracies for both latitude and year. In addition, there was little similarity between the natal signatures and the post-settlement signatures, and post-settlement classification rates were always higher when Acanthochromis polyacanthus signatures were used as the training data set, rather than the natal region of the otoliths. Such a decoupling between the natal and post-settlement region would be expected at the level of reefs, as it is possible that the source reef of fish was different to the reef on which they were collected. However, at the scale of latitude and year we would expect a good relationship between the natal portion and post-settlement portion of the otoliths. Although it is possible that fish were dispersed sufficiently large distances $(>1000 \mathrm{~km}$; Leis 1991) from their natal reefs that even large elemental differences like latitude and year were obscured, such a scenario seems unlikely.

There are several alternative explanations for the inconsistency noted between the natal and postsettlement regions of the Pomacentrus coelestis otoliths, including diet, protein content and ontogenetic variation. Although it has been assumed that water chemistry, as altered by temperature, is the primary source of ions found in otoliths, several studies have suggested that diet may also play a substantial role (Kennedy et al. 2000, Milton \& Chenery 2001). As food sources can be patchy, even at small spatial scales (100s of $\mathrm{m}$ to $\mathrm{kms}$; Sanchez-Jerez et al. 2002), some larvae may be exposed to prey items to which other larvae are not exposed, potentially altering otolith chemistry. Such a mechanism may explain differences in post-settlement $\mathrm{Sr} / \mathrm{Ca}$ and $\mathrm{Mg} / \mathrm{Ca}$ ratios within reefs. The portion of the otolith we defined as 'natal' coincided with the period during which the larvae would be feeding from the yolk sac ( $3 \mathrm{~d}_{i}$ Thresher 1984). Thus, it is possible that the composition of the yolk sac (i.e. maternal influences) affected the otolith chemistry of the larvae, obscuring the environmental signature, and decoupling the natal and post-settlement elemental signatures.
A second hypothesis is that differences in the template of the natal and post-settlement regions would affect the depositional process. Protein makes up only $\sim 3$ to $4 \%$ of the otolith by weight (Campana 1999). However, the core itself is comprised mostly of protein, and the 'natal' area defined in our study was comprised mainly of the core. Although trace elements can be associated with the proteinaceous matrix of otoliths (e.g. S: Kalish 1989, Na: Radtke \& Shafer 1992), this association has not been well studied, and the most common elements found in otoliths (e.g. $\mathrm{Sr}, \mathrm{Mg}, \mathrm{Ba}$ ) appear to substitute directly for Ca (Campana 1999). Several studies examining the composition of otoliths and eye lenses, which are composed mainly of protein ( $50 \%$; de Jong 1981), have indicated that the 2 structures have affinities for different elements (Dove \& Kingsford 1998, Gillanders 2001). Thus, it seems likely that the protein-rich core of the otoliths may take up a different suite of trace elements than otolith portions formed later in life.

Finally, ontogenetic changes in elemental deposition may alter the way in which ions are integrated into the aragonite matrix. Such changes have been noted in previous studies (Fowler et al. 1995), and may be related to physiological changes. For example, several studies have noted an increase in $\mathrm{Sr} / \mathrm{Ca}$ ratios at metamorphosis (Otake et al. 1994, Tzeng 1996) and with fish age (Proctor et al. 1995). This Sr/Ca peak is probably related to a drop in growth rate and a corresponding drop in protein synthesis (Campana 1999). Although studies on the effect of physiological changes on otolith chemistry have been largely restricted to adults (see Kalish 1991), it is possible that changes experienced by fish after settlement and during metamorphosis might influence otolith composition.

In summary, this study has demonstrated that elemental signatures in Pomacentrus coelestis may discriminate between clusters of reefs in the northern and southern GBR. Although some individual reefs within clusters showed persistent trends, the discrimination of fishes at the level of individual reefs remains elusive. The difficulty in discriminating among reefs within clusters is probably due to variation within reefs, as well as exposure to similar water masses. We also demonstrated that elemental signatures at the level of latitude and year were similarly recorded in the postsettlement portion of $P$. coelestis and Acanthochromis polyacanthus otoliths. Such continuity of elemental signatures supports the idea that water chemistry is a predominant factor driving elemental concentration in otoliths, at least over large spatial and temporal scales. This continuity did not apply to the natal portion of the $P$. coelestis otoliths, and classification rates based on natal signatures were always less accurate than post- 
settlement signatures, particularly for year. The reason(s) for this are unknown, as several mechanisms could explain the discontinuity. These results have great implications for future studies attempting to use the natal portion of otoliths to estimate self-recruitment or determine natal reef, as these studies will have to overcome the noted difficulties of working with the natal portion of otoliths.

Acknowledgements. We thank the staff of the Lizard Island and One Tree Island Research Stations, as well as J. Browne, I. Carlson, S. Burgess, J. Eagle, J. Hughes, A. Abdulla, R. Pears, R. Kelley, and the crew of the MV 'James Cook' for assistance in the field. M. Shelley, D. Sinclair, L. Kinsley, S. Fallon, T. Wyndham, and S. Eggins provided assistance with the LA-ICP-MS analysis. Statistical advice was provided by M. Sheaves and B. Gillanders. Comments by T. Elsdon improved the manuscript. This study was conducted while H.M.P. held a Lizard Island Doctoral Fellowship from the Australian Museum. A CRC Reef Research Grant, GBRMPA Augmentative Research Grant, and a grant from the Lerner-Gray Fund for Marine Research from the American Museum of Natural History to H.M.P., as well as an ARC Large Grant, and a grant from the National Geographic Committee for Research \& Exploration to M.J.K. funded the project.

\section{LITERATURE CITED}

Barber PH, Palumbi SR, Erdmann MV, Moosa MK (2000) A marine Wallace's line? Nature 406:692-693

Burrage D, Hughes R, Bode L, Williams D (1995) Dynamic features and transports of the Coral Sea circulation. In: Bellwood O, Choat JH, Saxena N (eds) Recent advances in marine science \& technology '94. James Cook University, Townsville, p 95-105

Caley MJ, Carr MH, Hixon MA, Hughes TP, Jones GP, Menge BA (1996) Recruitment and the local dynamics of open marine populations. Ann Rev Ecol Syst 27:477-500

Campana SE (1999) Chemistry and composition of fish otoliths: pathways, mechanisms and applications. Mar Ecol Prog Ser 188:263-297

Cowen RK, Lwiza KMM, Sponaugle S, Paris CB, Olson DB (2000) Connectivity of marine populations: open or closed? Science 287:857-859

de Jong WW (1981) Evolution of lens and crystallins. In: Bloemendal $\mathrm{H}$ (ed) Molecular and cellular biology of the eye lens. John Wiley, New York, p 221-278

Dove SG, Kingsford MJ (1998) Use of otoliths and eye lenses for measuring trace-element incorporation in fishes: a biogeographic study. Mar Biol 130:377-387

Dove SG, Gillanders BM, Kingsford MJ (1996) An investigation of chronological differences in the deposition of trace metals in the otoliths of two temperate reef fish. J Exp Mar Biol Ecol 205:15-33

Edmonds JS, Caputi N, Moran MJ, Fletcher WJ, Morita M (1995) Population discrimination by variation in concentrations of minor and trace elements in sagittae of two Western Australian teleosts. In: Secor DH, Dean JM, Campana SE (eds) Recent developments in fish otolith research. University of South Carolina Press, Columbia, SC, p 655-670

Edmonds JS, Steckis RA, Moran MJ, Caputi N, Morita M (1999) Stock delineation of pink snapper and tailor from
Western Australia by analysis of stable isotope and strontium/calcium ratios in otolith carbonate. J Fish Biol 55: 243-259

Eggins SM, Kinsley LPJ, Shelley JMG (1998) Deposition and fractionation processes during atmospheric pressure laser sampling for analysis by ICP-MS. Appl Surface Sci 127-129:278-286

Fisher R, Bellwood DR, Job SD (2000) Development of swimming abilities in reef fish larvae. Mar Ecol Prog Ser 202: 163-173

Flood MJ (2000) Otolith microstructure in pre- and postsettlement Pomacentrus coelestis (Pisces: Pomacentridae). Honours thesis, University of Sydney

Fowler AJ, Campana SE, Jones CM, Thorrold SR (1995) Experimental assessment of the effect of temperature and salinity on elemental composition of otoliths using laser ablation ICPMS. Can J Fish Aquat Sci 52:1431-1441

Gillanders BM (2001) Trace metals in four structures of fish and their use for estimates of stock structure. Fish Bull 99: 410-419

Gillanders BM, Kingsford MJ (2003) Spatial variation in elemental composition of otoliths of three species of fish (family Sparidae). Estuar Coast Shelf Sci 57:1049-1064

Haskew R (2002) Circulation around One Tree Reef, Great Barrier Reef, Australia. MSc thesis, University of Waikato, Hamilton

Jones GP, Milicich MJ, Emslie MJ, Lunow C (1999) Selfrecruitment in a coral reef fish population. Nature 402: 802-804

Kalish JM (1989) Otolith microchemistry: validation of the effects of physiology, age and environment on otolith composition. J Exp Mar Biol Ecol 132:151-178

Kalish JM (1991) Determinants of otolith chemistry: seasonal variation in the composition of blood plasma, endolymph and otoliths of bearded rock cod Pseudophycis barbatus. Mar Ecol Prog Ser 74:137-159

Kennedy BP, Blum JD, Folt CL, Nislow KH (2000) Using natural strontium isotopic signatures as fish markers: methodology and application. Can J Fish Aquat Sci 57:2280-2292

Kimura M, Maruyama T (1971) Pattern of neutral polymorphism in a geographically structured population. Genet Res 18:125-131

Kingsford MJ, Leis JM, Shanks A, Lindeman KC, Morgan SG, Pineda J (2002) Sensory environments, larval abilities and local self-recruitment. Bull Mar Sci 70 (Suppl):309-340

Leis JM (1991) The pelagic stage of reef fishes: the larval biology of coral reef fishes. In: Sale PF (ed) The ecology of fishes on coral reefs. Academic Press, San Diego, p $183-230$

Leis JM, Carson-Ewart BM (1997) In situ swimming speeds of the late pelagic larvae of some Indo-Pacific coral-reef fishes. Mar Ecol Prog Ser 159:165-174

Milton DA, Chenery SR (2001) Sources and uptake of trace metals in otoliths of juvenile barramundi (Lates calcarifer). J Exp Mar Biol Ecol 264:47-65

Otake T, Ishii T, Nakahara M, Nakamura R (1994) Drastic changes in otolith strontium/calcium ratios in leptocephali and glass eels of Japanese eels Anguilla japonica. Mar Ecol Prog Ser 112:189-193

Proctor CH, Thresher RE, Gunn JS, Mills DJ, Harrowfield IR, Sie SH (1995) Stock structure of the southern bluefin tuna Thunnus maccoyii: an investigation based on probe microanalysis of otolith composition. Mar Biol 122:511-526

Radtke RL, Shafer DJ (1992) Environmental sensitivity of fish otolith microchemistry. Aust J Mar Freshw Res 43: 935-951

Roughgarden J, Gaines S, Possingham H (1988) Recruitment 
dynamics in complex life cycles. Science 241:1460-1466

Sanchez-Jerez P, Gillanders BM, Kingsford MJ (2002) Spatial variation in abundance of prey and diet of trumpeter (Pelates sexlineatus: Treaponidae) associated with Zostera capricorni seagrass meadows. Aust Ecol 27:200-210

Shulman MJ, Bermingham E (1995) Early life histories, ocean currents, and the population genetics of Caribbean reef fishes. Evolution 49:897-910

Sinclair DJ, Kinsley LPJ, McCulloch MT (1998) High resolution analysis of trace elements in corals by laser ablation ICP-MS. Geochim Cosmochim Acta 62:1889-1901

Sponaugle S, Cowen RK, Morgan SG, Leis JM and 6 others (2002) Predicting self-recruitment in marine populations: biophysical correlates and mechanisms. Bull Mar Sci 70 (Suppl):341-375

Stobutzki IC, Bellwood DR (1997) Sustained swimming abilities of the late pelagic stages of coral reef fishes. Mar Ecol Prog Ser 149:35-41

Strathmann RR, Hughes TR, Kuris AM, Lindeman KC, Morgan SG, Pandolfi JM, Warner RR (2002) Evolution of local recruitment and its consequences for marine populations. Bull Mar Sci 70(Suppl):377-396

Swearer SE, Caselle JE, Lea DW, Warner RR (1999) Larval retention and recruitment in an island population of a coral-reef fish. Nature 402:799-802

Swearer SE, Shima JS, Hellberg ME, Thorrold SR and 6 others (2002) Evidence of self-reproduction in demersal marine populations. Bull Mar Sci 70(Suppl):251-271

Swearer SE, Forrester GE, Steele MA, Brooks AJ, Lea DW (2003) Spatio-temporal and interspecific variation in

Editorial responsibility: Otto Kinne (Editor),

Oldendorf/Luhe, Germany otolith trace-elemental fingerprints in a temperate estuarine fish assemblage. Estuar Coast Shelf Sci 56:1111-1123

Taylor MS, Hellberg ME (2003) Genetic evidence for local retention of pelagic larvae in a Caribbean reef fish Science 299:107-109

Thorrold SR, Jones GP, Hellberg ME, Burton RS, Swearer SE, Neigel JE, Morgan SG, Warner RR (2002) Quantifying larval retention and connectivity in marine populations with artificial and natural markers. Bull Mar Sci 70(Suppl): 291-308

Thorson G (1950) Reproductive and larval ecology of marine bottom invertebrates. Biol Rev 25:1-45

Thresher RE (1984) Reproduction in reef fishes. TFH Publications, Neptune City, NJ

Tzeng WN (1996) Effects of salinity and ontogenetic movements on strontium:calcium ratios in the otoliths of the Japanese eel, Anguilla japonica. J Exp Mar Biol Ecol 199: 111-122

Underwood AJ, Petraitis PS (1993) Structure of intertidal assemblages in different locations: how can local processes be compared? In: Ricklefs R, Schultz D (eds) Species diversity in ecological communities. University of Chicago Press, Chicago, p 38-51

Williams DM, Wolanski E, Andrews JC (1984) Transport mechanisms and the potential movement of planktonic larvae in the central section of the Great Barrier Reef. Coral Reefs 3:229-236

Wilson DT, McCormick MI (1999) Microstructure of settlement-marks in the otoliths of tropical reef fishes. Mar Biol 134:29-41

Submitted: September 10, 2003; Accepted: December 31, 2003 Proofs received from author(s): March 22, 2004 